\title{
Implementation of Blended Learning in Teaching at the Higher Education Institutions of Pakistan
}

\author{
Saira Soomro ${ }^{1}$ \\ Department of Distance Continuing and Computer \\ Education, \\ University of Sindh, Elsa Kazi Campus, Sindh, Pakistan
}

\author{
Arjumand Bano Soomro ${ }^{2}$ \\ Institute of Information \& Communication Technology \\ University of Sindh Jamshoro, Pakistan
}

\begin{abstract}
Blended learning has emerged as one of the solutions to address the various needs of Higher Education Institutions around the world. Blended Learning is the combination of traditional classroom and online endeavour. It provides advantages of both face to face learning and e-learning. The main purpose of this study is to assess the adaptation level of blended learning in teaching process at Higher Education Institutions. This study carried out mixed method approach by using explanatory sequential model. Teachers of general public universities were included as the sample for this study. Questionnaire and interview techniques were used as data gathering tools. The main findings of this study showed that teachers have a positive perception for technology usage in teaching process. Most of the teachers possessed expertise in the use of different software and equipped with internet skills. The study concluded that in blended learning implementation, universities are still at awareness level and a lot of efforts are required for effective implementation of blended learning. It is recommended that the universities' administration should provide an extra computing infrastructure (e.g. servers, bandwidth, and storage capacity) to run the courses in blended format. We recommend that in strategic plan of the universities the blended learning should be well defined and highlighted.
\end{abstract}

Keywords-Blended learning; teaching-learning; university teachers

\section{INTRODUCTION}

The rise of globalization has put higher education at a prominent position both in national and international context. Universities are now considered as research platforms and are playing pivotal role into their national development. Universities have also become main contributors to economic growth through the development in the field of science and technology, and through the application of modern technology. Technology has opened wide vistas of communication and digital world. Higher Education institutes are now in more challenging position to accept these revolutionary changes, so they equip the students with the new challenges of digital world. According to [1] in $21^{\text {st }}$ century the use of technology became mandatory in all fields

\author{
Tariq Bhatti ${ }^{3}$ \\ Faculty of Education \\ University of Sindh, Elsa Kazi Campus, \\ Hyderabad-76080, Sindh, Pakistan
}

Najma Imtiaz $\mathrm{Ali}^{4}$

Department of Information Systems, International Islamic University, Kuala Lumpur, Malaysia/ Institute of Mathematics and Computer science, University of Sindh Jamshoro, Pakistan including Higher Education and the paradigm of Higher Education has changed with penetration of technology.

In developed countries, the technological revolution has brought radical change in the field of education, particularly in higher education. The concept of blended learning has thrived in the developed world and through blended learning rapid and innovative systems in educational institutions are touching new limits and bringing advancements for knowledge seekers. The use of blended learning in combination with traditional classroom reduces the load of lecture-based teaching, and dependence on printed material. This approach of blended learning has created innovation, flexibility, activeness and collaboration in teaching-learning process. With blended learning students can use online platforms at any time and anywhere. Blended learning generated a new model for peerto-peer interaction, peer-to-faculty interaction. Its incorporation in higher education institutions has decreased the cost of higher education [2]. Pakistan like other South Asian countries is going through many developmental changes regarding the use of technology in the field of education. In Pakistan the concept of e-Learning was first started at Allama Iqbal Open University (AIOU) in year 2000. The framework was called as Open Learning Institute of Virtual Education (OLIVE). The Virtual University (VU) of Pakistan started courses via ICT, and national TV channels. Besides these two universities no other public or professional universities in Pakistan have adopted the advanced technology systems in real spirit which include blended learning [12].

The Higher Education Commission (HEC) Pakistan has also taken various initiatives to introduce and promote the use of modern technology in higher educational institutions, which includes Online Lecturing and Net-Meeting using IP-Based Video Conferencing System, Broadband Facility, National Digital Library, Pakistan Education and Research Network [12]. According to [3] the developing countries like Pakistan would not be able to get advantage from blended learning until or unless, if the factors responsible for its adaptation are persistently present in higher education institutes; e.g. ICT 
penetration issues, computer literacy and hesitation to move away from traditional learning methods, electric power failures and English language barriers.

\section{A. Rationale for the Study}

The rise of Blended Learning System (BLS) has brought a paradigm shift in education and has left far-reaching impacts on higher education as well. In the developed countries the blended learning adaptation in higher education is quicker than in comparison to developing countries. This benefits the developed countries in producing trained and rich human resource from educational institutions. In case of Pakistan, the implementation of blended learning in the higher education institution is an emerging trend and facing resistance in the fully implementation in the universities. Therefore, this research carried out under title "Implementation of Blended Learning System in the Higher Education Institutions in Pakistan".

\section{B. Research Questions}

1) At what level blended learning is being implemented in teaching process in Higher Education Institutions?

2) What are the main problems \& challenges faced by Higher Education Institutions in the implementation of blended learning in teaching process?

\section{MethodOLOGY}

This research study incorporated "Explanatory Sequential Design", a mixed method approach also called two-phase model. According to [13] this model consists of first collecting quantitative data and then collecting qualitative data to help explain or elaborate on the quantitative results provide a general picture of the research problem. The sample for the research study comprised of all four (04) public sector general universities in the province of Sindh, Pakistan. The universities included namely are; i) University of Sindh Jamshoro (UOSJ), ii) University of Karachi (UOK), iii) Shah Abdul Latif University Khairpur (SALUK) and iv) Shaheed Benazir Bhutto University Shaheed Benazirabad (SBBUSB). Two (02) departments from each Social Sciences Faculty and Natural Sciences Faculty were selected through purposive sampling technique from each university. The selection of teachers from selected departments was done through random sampling technique. A questionnaire for this research was adopted from a study by [14] on blended learning. Five-point Likert scale was used for the quantitative questionnaire starting from strongly agree to strongly disagree, whereas $1=$ Strongly Agree (SA), 2= agree (A), 3= undecided (UD), 4= disagree (DA) and 5= strongly disagree (SDA

For data collection, the questionnaire was developed for university teachers, and it was administered to 58 male teachers and 27 female teachers. Out of 58 male teachers, 38 responded and out of 27 female teachers, 22 responded. Collected data was analyzed through the application of descriptive statistics (percentages, and mean score). Two teachers were also selected randomly from 04 departments of each selected university for qualitative data through interview protocol.
TABLE I. FinAL SAMPLE SIZE OF THE STUdY

\begin{tabular}{|l|l|l|l|l|l|l|}
\hline \multirow{2}{*}{ Universities } & \multicolumn{4}{|l|}{$\begin{array}{l}\text { Teachers at 50\% for } \\
\text { interview }\end{array}$} & \multicolumn{3}{|l|}{$\begin{array}{l}\text { Teachers at 30\% for } \\
\text { questionnaire }\end{array}$} \\
\cline { 2 - 7 } & Total & $\mathbf{5 0 \%}$ & F & $\mathbf{3 0 \%}$ & M & $30 \%$ \\
\hline UOSJ & 04 & 02 & 38 & 11 & 66 & 19 \\
\hline UOK & $\mathbf{0 4}$ & $\mathbf{0 2}$ & $\mathbf{3 0}$ & $\mathbf{0 9}$ & $\mathbf{6 2}$ & $\mathbf{1 8}$ \\
\hline SALUK & $\mathbf{0 4}$ & $\mathbf{0 2}$ & $\mathbf{1 5}$ & $\mathbf{0 4}$ & $\mathbf{3 8}$ & $\mathbf{1 1}$ \\
\hline SBBUSB & $\mathbf{0 4}$ & $\mathbf{0 2}$ & $\mathbf{1 1}$ & $\mathbf{0 3}$ & $\mathbf{3 4}$ & $\mathbf{1 0}$ \\
\hline $\begin{array}{l}\text { TOTAL } \\
\text { sample }\end{array}$ & & $\mathbf{0 8}$ & & 27 & & $\mathbf{5 8}$ \\
\hline
\end{tabular}

Table I shows the final sample size of respondent. There were 04 respondents for interview and the researcher chooses the $50 \%$ for the interview i.e. 2 from each university. For questionnaire the researcher choose the $30 \%$ of total respondent i.e. 11 female and 19 male from UOSJ, whereas 9 female and 18 male from UOK; furthermore 4 female and 11 male from SALUK and 3 female and 10 male from SBBUSB.

Table II shows the age of the respondent. The respondent in the range of 25-30 from all four universities were 6,4,3 and respectively, whereas respondent in the range of 31-40 were $11,12,4$, and 7. Furthermore the respondents in the range of 4150 were 7,5,4 and 2 respectively and the respondent in the range of 51- 60 from all the 4 universities were 6, 64 and 1 female and 11 male from SALUK and 3 female and 10 male from SBBUSB

TABLE II. AGE WISE DISTRIBUTION OF SAMPLE OF THE STUDY

\begin{tabular}{|l|l|l|l|l|}
\hline \multirow{2}{*}{ Universities } & \multicolumn{4}{|l|}{ Age wise distribution of teachers in years } \\
\cline { 2 - 6 } & $\begin{array}{l}25- \\
30\end{array}$ & $31-40$ & $41-50$ & $51-60$ \\
\hline UOSJ & 6 & 11 & 7 & 6 \\
\hline UOK & 4 & 12 & 5 & 6 \\
\hline SALUK & 3 & 4 & 4 & 4 \\
\hline SBBUSB & 3 & 7 & 2 & 1 \\
\hline
\end{tabular}

TABLE III. DESIGNATION WISE DISTRIBUTION OF SAMPLE OF THE STUDY

\begin{tabular}{|l|l|l|l|l|}
\hline \multirow{2}{*}{ Universities } & \multicolumn{4}{|c|}{ Designation wise distribution of teachers } \\
\cline { 2 - 5 } & Lecturer & $\begin{array}{l}\text { Assistant } \\
\text { Professor }\end{array}$ & $\begin{array}{l}\text { Associate } \\
\text { Professor }\end{array}$ & Professor \\
\hline UOSJ & 09 & 12 & 04 & 05 \\
\hline UOK & 10 & 10 & 04 & 03 \\
\hline SALUK & 03 & 06 & 03 & 03 \\
\hline SBBUSB & 06 & 05 & 02 & 00 \\
\hline
\end{tabular}


TABLE IV. ACADEMIC QUALIFICATION WISE DISTRIBUTION OF SAMPLE

\begin{tabular}{|l|l|l|l|}
\hline \multirow{2}{*}{ Universities } & \multicolumn{3}{|l|}{$\begin{array}{l}\text { Academic qualification wise distribution of } \\
\text { teachers }\end{array}$} \\
\cline { 2 - 4 } & Master's & M.Phil & Doctorate \\
\hline UOSJ & 09 & 13 & 8 \\
\hline UOK & 10 & 11 & 6 \\
\hline SALUK & 03 & 07 & 5 \\
\hline SBBUSB & 06 & 05 & 2 \\
\hline
\end{tabular}

Table III shows the designation wise distribution of sample size. There were 9 lecturers 1 assistant professor, 4 associate professor and 5 professor from UOSJ. Similarly for UOK there were 10 lecturers, 10 assistant professors, 4 associate professors and 3 professors. Furthermore for SALUK and SBBUSB the respondent distribution was 3, 6, 3, 3 and 6, 5, 2 and 0 respectively.

Table IV present the academic qualification of the respondent. There were 9 masters, 13 Mphil and 8 Doctorate from UOSJ and similarly 10, 11 and 6 from UOK. Furthermore there were 3 masters 7 Mphil and 5 Doctorate from SALUK and similarly 6, 5 and 2 from SBBUSB.

\section{DATA ANALYSIS}

Table V shows that higher number of respondents $18.33 \%$ teachers strongly agreed, and $33.33 \%$ teachers agreed that they were advance users of Email service for teaching-learning process whereas $21.67 \%$ and $16.76 \%$ respondents were disagreed and strongly disagreed respectively. While $10.00 \%$ remain undecided. The mean score found to be 3.13. Thus, the result described that most of the teachers rated themselves as advanced users of Email service for teaching-learning process.

TABLE V. OPINION REGARDING LEVEL OF EXPERTISE IN USING EMAIL SERVICE FOR TEACHING PROCESS

\begin{tabular}{|l|l|l|l|l|l|l|}
\hline Scale & SA & A & UD & DA & SDA & Mean \\
\cline { 1 - 5 } Frequency & 11 & 20 & 06 & 13 & 10 & \multirow{2}{*}{3.13} \\
\cline { 1 - 5 } Percentage & $18.33 \%$ & $33.33 \%$ & $10.00 \%$ & $21.67 \%$ & $16.67 \%$ & \\
\hline
\end{tabular}

TABLE VI. OPINION REGARDING THE LEVEL OF EXPERTISE IN USING SEARCH ENGINES FOR TEACHING PROCESS

\begin{tabular}{|l|l|l|l|l|l|l|}
\hline Scale & SA & A & UD & DA & SDA & Mean \\
\cline { 1 - 5 } Frequency & 12 & 23 & 10 & 08 & 07 & \multirow{2}{*}{3.4} \\
\cline { 1 - 5 } Percentage & $20.00 \%$ & $38.33 \%$ & $16.67 \%$ & $13.33 \%$ & $11.67 \%$ & \\
\hline
\end{tabular}

Table VI shows the majority of teachers $20.00 \%$ strongly agreed, $38.33 \%$ agreed that they were advance users of search engines for teaching process, while $13.33 \%$ teachers disagreed and $11.67 \%$ strongly disagreed with the statement. Whereas $16.67 \%$ teachers remained undecided. The mean score found to be 3.4. Thus, the results show that most of the teachers rated themselves as advanced users of search engines for teaching in the classrooms.
TABLE VII. OPINION REGARDING LEVEL OF EXPERTISE IN USING WEB 2.0 TOOLS FOR TEACHING PROCESS

\begin{tabular}{|c|c|c|c|c|c|c|}
\hline Scale & SA & A & UD & DA & SDA & Mean \\
\cline { 1 - 6 } Frequency & 14 & 17 & 05 & 15 & 09 & 3.16 \\
\cline { 1 - 5 } Percentage & $23.33 \%$ & $38.33 \%$ & $8.33 \%$ & $25.00 \%$ & $15.00 \%$ & \\
\hline
\end{tabular}

TABLE VIII. OPINION REGARDING TEACHER'S AWARENESS OF THE BENEFITS OF BLENDED LEARNING FOR TEACHING-LEARNING PROCESS

\begin{tabular}{|l|l|l|l|l|l|l|}
\hline Scale & SA & A & UD & DA & SDA & Mean \\
\hline Frequency & 15 & 18 & 04 & 10 & 13 & \multirow{2}{*}{3.28} \\
\cline { 1 - 6 } Percentage & $25.00 \%$ & $30.00 \%$ & $6.67 \%$ & $16.67 \%$ & $21.67 \%$ & \\
\hline
\end{tabular}

Table VII shows that the majority of teachers $23.33 \%$ strongly agreed, $38.33 \%$ teachers agreed that they were advance users of Web 2.0 tools for teaching process, whereas $25.00 \%$ of teachers were disagreed and $15.00 \%$ were strongly disagreed that they were basic users. While $8.33 \%$ teachers remained undecided. The mean score found to be 3.16. Thus, results show that most of the teachers rated themselves as advanced users of Web 2.0 tools for teaching.

Table VIII shows that majority of teachers with $25.00 \%$ and $30.00 \%$ were strongly agreed and agreed respectively that they were aware of the benefits of blended learning for teaching process, $16.67 \%$ of teachers disagreed, $21.67 \%$ of teachers strongly disagreed that they were unaware of the benefits of blended learning whereas $6.67 \%$ teachers remained undecided. The mean score is found to be 3.28. Thus, the results indicate that most of the teachers were aware of the benefits of blended learning for teaching process.

TABLE IX. OPINION REGARDING THE TEACHERS SUPPORT FOR BLENDED LEARNING IN TEACHING PROCESS

\begin{tabular}{|l|l|l|l|l|l|l|}
\hline Scale & SA & A & UD & DA & SDA & Mean \\
\cline { 1 - 6 } Frequency & 15 & 18 & 08 & 09 & 10 & \multirow{2}{*}{3.31} \\
\cline { 1 - 5 } Percentage & $25.00 \%$ & $30.00 \%$ & $13.33 \%$ & $15.00 \%$ & $16.67 \%$ & \\
\hline
\end{tabular}

TABLE X. OPINION REGARDING THE TEACHER'S VIEWS ABOUT UNIVERSITY POLICY FOR BL FOR TEACHING PROCESS

\begin{tabular}{|l|l|l|l|l|l|l|}
\hline Scale & SA & A & UD & DA & SDA & Mean \\
\cline { 1 - 6 } Frequency & 04 & 05 & 12 & 19 & 20 & \multirow{2}{*}{2.17} \\
\cline { 1 - 6 } Percentage & $6.67 \%$ & $8.33 \%$ & $20.00 \%$ & $31.67 \%$ & $33.33 \%$ & \\
\hline
\end{tabular}

Table IX shows that the majority of teachers $25.00 \%$ strongly agreed and $30.00 \%$ agreed that they were supporter of blended learning approach for teaching process, $15.00 \%$ of teachers disagreed with the statement whereas $16.67 \%$ strongly agreed. While $13.33 \%$ teachers remained undecided. The mean score found to be 3.31. Thus, the results show that most of the teachers were in supporter of blended learning approach in teaching.

Table X exhibits a small number of teachers $6.67 \%$ strongly agreed and $8.33 \%$ agreed with the statement that they knew about their university policy for BL for teaching 
process, majority of teachers $31.67 \%$ shown their disagreed, $33.33 \%$ were strongly disagreed that they did not knew about their university policy and $20.00 \%$ teachers remained undecided. The mean score is found to be 2.17. Thus, the results show that a very small number of the teachers responded that they knew their university have any policy for blended learning for teaching process.

TABLE XI. OPINION REGARDING TEACHERS' VIEWS ABOUT BLENDED LEARNING MODEL ADOPTION BY UNIVERSITY FOR TEACHING PROCESS

\begin{tabular}{|l|l|l|l|l|l|l|}
\hline Scale & SA & A & UD & DA & SDA & Mean \\
\hline Frequency & 03 & 05 & 13 & 16 & 23 & \multirow{2}{*}{2.1} \\
\hline Percentage & $5.00 \%$ & $8.33 \%$ & $21.67 \%$ & $26.67 \%$ & $38.33 \%$ & \\
\hline
\end{tabular}

Table XI shows teacher's views about Blended Learning model adoption by university for teaching process. Analysis of data exhibits a small number of teachers $5.00 \%$ were strongly agreed, $8.33 \%$ were agreed that they knew about their university model for $\mathrm{BL}$ for teaching-learning process, a majority of teachers with $26.67 \%$ and $38.33 \%$ ratio were disagreed and strongly disagreed respectively, and did not knew about their university model while $21.67 \%$ teachers remained undecided. The mean score is 2.1 . The results show that a very small number of the teachers knew that their university has any model for blended learning for teachinglearning process.

TABLE XII. OPINION ABOUT COURSE DESIGN ON BLENDED LEARNING

\begin{tabular}{|l|l|l|l|l|l|l|}
\hline Scale & SA & A & UD & DA & SDA & Mean \\
\hline Frequency & 02 & 03 & 13 & 17 & 25 & \multirow{2}{*}{1.95} \\
\hline Percentage & $3.33 \%$ & $5.00 \%$ & $21.67 \%$ & $28.33 \%$ & $41.67 \%$ & \\
\hline
\end{tabular}

Table XII shows a small number of teachers $8.33 \%$ agreed that they knew about course design on Blended Learning for teaching process, a majority of teachers $70.00 \%$ disagreed and did not know about course design and $21.67 \%$ teachers remained undecided. The mean score is found to be 1.95 . The results show that a very small number of the teachers knew that their university have designed course on blended learning format for teaching-learning process.

TABLE XIII. OPINION REGARDING TEACHERS VIEWS ABOUT TRAINING RELATED TO BLENDED LEARNING COURSE DESIGN

\begin{tabular}{|l|l|l|l|l|l|l|}
\hline Scale & SA & A & UD & DA & SDA & Mean \\
\hline Frequency & 18 & 24 & 05 & 06 & 07 & \multirow{2}{*}{3.65} \\
\cline { 1 - 5 } Percentage & $30.00 \%$ & $40.00 \%$ & $8.33 \%$ & $10.00 \%$ & $11.67 \%$ & \\
\hline
\end{tabular}

Table XIII shows that majority of teachers $30.00 \%$ strongly agreed, $40.00 \%$ agreed that they need trainings for blended learning course design, whereas $10.00 \%$ of teachers disagreed, $11.67 \%$ of teachers strongly disagreed that they did not want trainings for blended learning course design. While $8.33 \%$ teachers remained undecided. The mean score is found to be 3.65 . The result shows that majority of teachers want trainings for designing courses on blended learning format for teaching process.
TABLE XIV. OPINION REGARDING TEACHERS VIEWS ABOUT TRAINING RELATED TO USE OF OER FOR BLENDED LEARNING COURSE

\begin{tabular}{|l|l|l|l|l|l|l|}
\hline Scale & SA & A & UD & DA & SDA & Mean \\
\hline Frequency & 16 & 28 & 03 & 04 & 09 & \multirow{2}{*}{3.56} \\
\cline { 1 - 6 } Percentage & $26.67 \%$ & $46.67 \%$ & $5.00 \%$ & $6.67 \%$ & $15.00 \%$ & \\
\hline
\end{tabular}

Table XIV shows that majority of teachers with $26.67 \%$ were strongly agreed, $46.67 \%$ were agreed that they need trainings for use of Open Education Resource (OER) for blended learning course, whereas a small proportion of teachers with $6.67 \%$ were disagreed and $15.00 \%$ teachers were strongly disagreed and did not want trainings of OER for blended learning course. While $5.00 \%$ teachers remained undecided. The mean score is found to be 3.56. The result shows that majority of teachers want trainings of OER for blended learning course.

TABLE XV. OPINION REGARDING TEACHERS VIEWS ABOUT TRAINING FOR TECHNICAL STAFF FOR IMPLEMENTATION OF BLENDED LEARNING COURSE

\begin{tabular}{|l|l|l|l|l|l|l|}
\hline Scale & SA & A & UD & DA & SDA & Mean \\
\hline Frequency & 17 & 26 & 04 & 06 & 07 & \multirow{2}{*}{3.33} \\
\cline { 1 - 5 } Percentage & $28.33 \%$ & $43.33 \%$ & $6.67 \%$ & $10.00 \%$ & $15.00 \%$ & \\
\hline
\end{tabular}

Table XV. shows that majority of teachers $28.33 \%$ strongly agreed, $43.33 \%$ agreed that they need trainings for technical staff for implementation of Blended Learning course, $10.00 \%$ of teachers were disagreed, $15.00 \%$ teachers were strongly disagreed did not want trainings while $6.67 \%$ teachers remained undecided. The mean score is found to be 3.33. The results show that majority of teachers want trainings .for technical staff for implementation of Blended Learning course.

TABLE XVI. OPINION REGARDING TEACHER'S VIEWS ABOUT POTENTIAL CHALLENGES OF TEACHING THROUGH BLENDED MODE TAKES MORE TIME EFFORT

\begin{tabular}{|l|l|l|l|l|l|l|}
\hline Scale & SA & A & UD & DA & SDA & Mean \\
\cline { 1 - 5 } Frequency & 16 & 28 & 03 & 04 & 09 & \multirow{2}{*}{3.56} \\
\cline { 1 - 5 } Percentage & $26.67 \%$ & $46.67 \%$ & $5.00 \%$ & $6.67 \%$ & $15.00 \%$ & \\
\hline
\end{tabular}

Table XVI shows that majority of teachers $26.67 \%$ strongly agreed, $46.67 \%$ agreed that teaching through blended modell is a challenge and takes more effort, $6.67 \%$ of teachers disagreed, $15.00 \%$ were strongly disagreed that they did not consider it a challenge. While $5.00 \%$ teachers remained undecided. The mean score is found to be 3.56. The results show that majority teachers consider teaching though blended mode a challenge.

TABLE XVII. OPINION REGARDING MANY TEACHERS HAVE YET TO ACCEPT THE VALUE BLENDED LEARNING

\begin{tabular}{|l|l|l|l|l|l|l|}
\hline Scale & SA & A & UD & DA & SDA & Mean \\
\cline { 1 - 5 } Frequency & 18 & 24 & 05 & 06 & 07 & \multirow{2}{*}{3.65} \\
\cline { 1 - 5 } Percentage & $30.00 \%$ & $40.00 \%$ & $8.33 \%$ & $10.00 \%$ & $11.67 \%$ & \\
\hline
\end{tabular}


Table XVII shows that majority of teachers $30.00 \%$ strongly agreed, $40.00 \%$ of teachers agreed that faculties needs to accept the value of teaching through blended mode. $10.00 \%$ of teachers were disagreed, $11.67 \%$ were strongly disagreed and did not consider acceptance as a challenge while $8.33 \%$ teachers remained undecided. The mean score is found to be 3.65 . The results show that majority of faculties needs to accept the value of teaching through blended mode.

\section{ANALYSIS OF DATA COLLECTED FROM TEACHERS THROUGH INTERVIEWS}

The interviews were conducted and analysed through discussion under the themes as follows:

\section{A. Theme 01: Integration of Technology}

Most of the participants stated that; they use computers for different activities, such as for research, lecture and presentation purpose, teachers are expert in using MS Office. Most of the teachers are expert in using e-mails and search engines for teaching-learning process, all teachers have their official email addresses given by the universities. Most of the teachers are familiar and use of web 2.0 tools like blogs and discussion forums. Most of teachers are members of professional and academic networks like academia, research gate, and LinkedIn as suggested by [4].

\section{B. Theme 02: Level of Implementation of Blended Learning}

Teachers viewed that; each individual faculty knows about the term Blended Learning, and its benefits. Even though individual faculty members are not implementing Blended Learning in their teaching process, but they advocate its need. The participants observed that faculty is not able to implement blended learning due to several reasons like lack of authorization and some exterior issues such as; no appropriate trainings of staff and teachers; and limited number of computer labs for students, no uniform definition of Blended Learning recommended officially and no office definition, no uniform Blended Learning policy is there and no strategy or no course of action, no orientation for Blended Learning, no official endorsement or no guideline for implementation of blended learning in the system, no institutional models established, or any model adopted, no courses on the blended learning format is identified in catalogues before start of any semester, there is no course is being designed yet on the blended learning format, no course is designed, which supports the Blended Learning pedagogy/instructional methods. The above same findings of understanding and examination of first phase are supported and discussed in "Blended Learning adoption and framework" by [5]. Initially, researcher assumed that University of Karachi and University of Sindh be considered at second level of early implementation phase as they both universities are urban universities and run the Directorate of Distance Education Program, a Higher Education Commission HEC, Pakistan funded project. The rest of the two universities Shah Abdul Latif University, Khairpur and Shaheed Benazir Bhutto University, Shaheed Benazirabad were assumed at first level of awareness level. But after interviews and data collection is was analyzed that all four universities of Sindh province are at same page and touches only first stage that is awareness.

\section{Theme 03: Challenges}

The challenges encompassed that there is no motivation and encouragement for the teachers who are using BL components into their teaching, faculty needs trainings for using OER for Blended Learning courses and faculty needs trainings for designing Blended Learning courses.

From questionnaires and interviews of teachers it is concluded that they face problems in adopting blended learning. Some of the challenges were identified as [6];

- No policy for blended learning implementation;

- No faculty support and training to initiate courses on blended format

- Lack specialized skills needed to run courses on blended format; and

- Shortage of computer laboratories to run courses on blended format.

From the participant views and questionnaire results it is clearly shown that the external factors mentioned above were affecting teachers' willpower and distracting their motivation of not opting the course on blended format. Due to lack of universities support the teachers' demands a proper system for implementation

\section{DISCUSSION AND CONCLUSION}

The blended learning is a new concept in Pakistan which is an underdeveloped country and has not embraced it in education. Therefore participants' trend going towards in positive direction as they are aware of it but still it's not found implemented yet. Teachers gave great importance to policies on using ICT for blended learning, and were familiar with the benefits of Blended Learning. Teachers were supporter and promoter of the Blended Learning but with no constant definition of Blended Learning, no course of action or no official approval they were at awareness level for implementation of Blended Learning. Teaching through blended mode was a time consuming, needs more efforts. Acceptation of blended instruction was a main barrier in implementation blended learning. Teachers prerequisite faculty development trainings regarding blended learning system and considered lack of funding was one of challenge for purchasing the equipment and software needed for blended learning. Moreover, teachers viewed that there was need for technical skills, assistance and support for technical problems in the implementation of blended learning system. Along with this they agreed that there was no faculty motivation or encouragement or incentive for the teachers, who were using BL components into their teaching at their own. [7]indicate that teaching blended courses can give the lecturer the opportunity to use new educational technology in the universities.[8] describes that blended learning is proficient and effective" (p. 6). A study conducted a study that explored majority of students' favoured blended learning mode because of the flexibility and convenience and Blended learning facilitate students to express the level of freedom in interacting with their peers [9].

Furthermore, they viewed that there was no model, no 
course, no any official definition was there for the implementation of Blended Learning. It is also concluded that majority of teachers gave great importance to policies on using ICT for blended learning, and were familiar with the benefits of Blended Learning. There was no policy of Blended Learning was being informed by Head of Departments to concerned teachers because that there was no official approval or order, no policy, no course was being designed for the implementation of Blended Learning was planned or scheduled. According [10] in blended learning students can take advantage and proceed their learning at any time, any place at their own convenience due to its flexible nature. Blended Learning is easy in comparison to traditional face to face where time limitation and space is decided in advance and students needs to be present there if they want to learn.

It is concluded that teachers perceived that teaching through blended mode was a time consuming, needs more efforts. Acceptation of blended instruction was a main barrier in implementation blended learning. Teachers prerequisite faculty development trainings regarding blended learning system and considered lack of funding was one of challenge for purchasing the equipment and software needed for blended learning. Moreover, they viewed that there was need for technical skills, assistance and support for technical problems in the implementation of blended learning system. Along with this they agreed that there was no faculty motivation or encouragement or incentive for the teachers, who were using BL components into their teaching at their own. Furthermore, they viewed that there was no model, no course, no any official definition was there for the implementation of Blended Learning. [11] said that Blended learning is combining both potentials of face to face and online instructions. It's not the new, but a novel idea of incorporating technology with traditional methods of teaching to equip students with 21 stcentury skills i.e. collaboration, creativity and problemsolving skills are core areas where students expect them to become enable.

\section{RECOMMENDATIONS}

This research gives few recommendations as follows:

- The university administration should provide extra computing infrastructure (servers, bandwidth, and storage capacity) to run courses in blended format.

- Universities should develop comprehensive institutional and organizational mechanisms to implement blended learning.

- In strategic plan of the universities the blended learning should be well defined and highlighted.

- In Policies and planning, the universities administration should focus on implementation of blended learning in courses.

- The Heads of the departments should also develop a comprehensive mechanism for the effective implementation of blended learning in teachinglearning process.

- The technology-based centralized resource centre should be established to provide technical support \& guidance to the teachers.

- The Learning Management System should be introduced at department level through the technologybased centralized resource centre.

- The university courses should be revised, and technological aspect must be included in the course.

- Conferences, seminar on blended learning should be organized in collaboration with virtual university Pakistan and other technology sufficient institutions.

- The separate budgetary heads should be maintained for the purchase $\&$ provision of equipment and software needed for blended learning.

\section{REFERENCES}

[1] Young, J. R. (2002). 'Hybrid' Teaching Seeks to End the Divide between Traditional and Online Instructions. The Chronicle of Higher Education, 48(28), p33.

[2] Morgan, K. R. (2002). Blended learning: A strategic action plan for a new campus. Seminole:University of Central Florida.

[3] Qureshi. A \&etal (2012)" Challenges of implementing e-learning in a Pakistani university" Knowledge Management \& E-Learning: An International Journal, Vol.4, No.3, Pp 310-324.

[4] Ndereya. N.C (2014)"Implementing Blended Learning at a Developing University: Obstacles in the way" The Electronic Journal of e-Learning Volume 12 Issue 1 2014, (pp101-110).

[5] Graham, Charles, R., Woodfield, W., \& Harrison, J. B. (2013). A framework for institutional adoption and implementation of blended learning in higher education. Internet and Higher Education. doi:10.1016/j.iheduc.2012.09.003

[6] Alebaikan. A. R.(2010) Perceptions of Blended Learning in Saudi Universities: Ph.D thesis

[7] SARAH E. KING AND KATIE CERRONE ARNOLD (2009) "Blended Learning Environments in Higher Education: A Case Study of How Professors Make it Happen" Journal of Mid-Western Educational Researcher Volume 25, Issues 1/2, Pp 44-59. Seminole, FL: University of Central Florida.

[8] Harvey Singh. (2003). "Building Effective Blended Learning Programs, Issue of Educational Technology". Volume 43. Number 6, Pages 51-54.

[9] Kistow.B (2011)" Blended learning in higher education: A study of a graduate school of business, Trinidad and Tobago" Journal of Caribbean Teaching Scholar,Vol. 1, No. 2, published by Educational Research Association(ERA), Pp 115-128.

[10] Singh, Harvey. (Nov-Dec, 2003). "Building effective blended learning programs".

[11] Garrison, D. R., \& Vaughan, N. D. (2008). Blended Learning in Higher Education: Framework, Principles, and Guidelines. San Francisco, CA: John Wiley \& Sons.

[12] Survey of ICTs for Education in India and South Asia, Case Studies 2010

[13] Creswell John W, (2012). "Educational Research Planning, Conducting, and Evaluating Quantitative and Qualitative Research", 4th Edition published by Pearson Education, Inc.

[14] Graham, C. R., Woodfield, W., \& Harrison, J. B. (2013). A framework for institutional adoption and implementation of blended learning in higher education. The internet and higher education, 18, 4-14. 